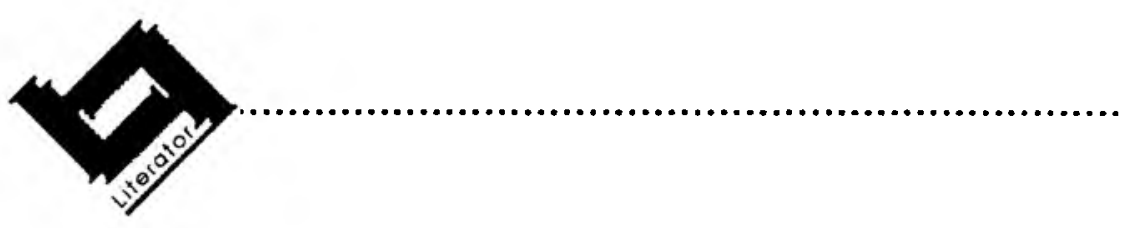

\title{
Reis as ondergrawing van meesterverhale: die reise van Ratkas en Isobelle
}

\author{
Willie Burger \\ Departement Afrikaans \\ Randse Afrikaanse Universltelt \\ JOHANNESBURG \\ E-pos: wdb@lw.rau.ac.za
}

\section{Abstract \\ Travel as the undermining of master narratives: The journeys of Ratkas and Isobelle}

Travelling usually leads to changed perspectives. The traveller becomes aware that his/her own perspective on reality is not the only valid perspective. In this article two Afrikaans novels in which travel is of central importance are examined to determine the manner in which these travels serve to undermine master narratives. Travels do not necessarily lead to a proliferation of perspectives and a postmodernist distrust of master narratives. In Die ryk van die rawe the traveller does not succeed in gaining a new perspective at all, while in Die reise van Isobelle, one master narrative is replaced by another - corresponding with Caren Kaplen's idea that master narratives are needed in order to change society.

\section{Reis en die ondergrawing van meesterverhale}

Om te reis is, volgens speurder Banaby in Die ryk van die rawe (Fouché, 1996), "om 'n leeftyd van gebeure in een liggaam te pak en die liggaam iewers heen te neem sodat daar bespiegel kan word oor die aard van die gebeure" (275)1. Reis en besinning oor die lewe gaan dus hand aan hand. Die verplasing van die liggaam na 'n ander ruimte, "iewers heen" verander die perspektief wat vanuit daardie liggaam moontlik is. Die verandering van ruimte lei daartoe dat anders 
gekyk word na die tuiste van waar oorspronklik gereis is. Reis, die pak van 'n leeftyd se gebeure in 'n liggaam en die neem daarvan "iewers heen" is dus 'n manier om 'n verandering van verwysingspunt teweeg te bring. So 'n verandering het tot gevolg dat die heersende (vorige) perspektief bevraagteken word.

Die vermeniguldiging van perspektiewe (waarvan die een nie meer betroubaar is as die ander nie), word dikwels as een van die kenmerke van die postmodernisme gereken. Aangesien reis (mobiliteit) aanleiding kan gee tot die ondergrawing van perspektiewe en die verplasing van perspektiewe deur ander moontlikhede, lê Caren Kaplan 'n verband tussen reis en postmodernisme in haar werk Ouestions of travel: Postmodem discourses of displacement (1996). Sy voel dat dit geregverdig is om hierdie verband te lê, aangesien reis 'n verandering meebring in die posisie van waaruit waargeneem word. Postmodernisme het vir haar te doen met die voortdurende verandering van die punt van waarneming, wat die ondergrawing van meesterverhale tot gevolg het. Daarom word die postmodernisme gekenmerk deur selfbewuste historiese relativisme, soos merkbaar ten opsigte van die problematiek van die plek van Westerse kultuur in verhouding tot die nieWesterse kultuur. Die postmodernisme is gemoeid met vraagstukke van posisie. Die posisie of verwysingspunt waarvandaan die kunstenaar of die outeur waarneem, word voortdurend geproblematiseer.

Sekerhede oor identiteit, die geskiedenis, die nasie, taaluitings en kulturele en estetiese skeidings word gedurig in postmodernistiese tekste ondergrawe. Veranderende perspektiewe, die ondergrawing van meesterverhale, kan dus ook gesien word as die ontvlugting van hegemoniese strukture. Die verwagting sou dus ook kon wees dat 'n reis, as 'n manier waarop voortdurend van perspektief verander word, moet lei tot die ontvlugting van onderdrukkende strukture.

Lyotard (1984) beskou die wantroue in meesterverhale as die belangrikste kenmerk van die postmodernisme. Ten spyte van uiteenlopende menings oor die postmodernisme, is hierdie wantroue in meesterverhale vir die meeste teoretici oor die postmodernisme die belangrikste enkele kenmerk daarvan. 'n Enkele, oorheersende perspektief word nie geduld nie. Die klem val eerder op 'n veelheid van perspektiewe. Die verval van meesterverhale lei vir Lyotard tot 'n oneindige netwerk van "klein verhale" (petit histoires). Veral veranderende perspektiewe op meesterverhale veroorsaak dat die "mitiese" begronding daarvan blootgelê word. Veranderende perspektiewe word onder andere teweeggebring deur reise. Kaplan (1996:14) stel dit soos volg:

Emergent theories of postmodemism, then, argues that the politics of difference are aided and even structured by the international circulation of destabilizing and multiplying cultural elements, events, and instances that 'clear a space' for new or previously unheard or unacknowledged narratives. 
Met die vertel van enige verhaal word sekere dinge weggelaat; alle moontlikhede kan nie gelyktydig vertel word nie. Wanneer 'n meesterverhaal dus 'n spesifieke slot in gedagte het, word alle ander slotte uitgesluit (wat altyd onbekend sal bly). Volgens Spivak (1990:21) is die doel van die werk van Derrida en Lyotard om voortdurend te probeer vasstel wat dit is wat weggelaat word deur die meesterverhale (deur enige narratiewe). Verandering van perspektief op meesterverhale lei dikwels daartoe dat waarheidsaansprake, etiese norme en verhewe ideale ontmasker word as praktyke wat slegs mag en eiebelang ('n spesifieke slot) in gedagte het. In hierdie verband kan reis dus beskou word as 'n poging om die slot af te weer.

Hans Bertens en Theo D'Haen stel voor dat die term postmodernisme as 'n heuristiese instrument gebruik moet word: "Met andere woorden, het hanteren van het begrip postmodernisme maakt, met de invulling die wij er aan geven, een bepaalde invalshoek mogelijk die een ander begrip ... niet kan verschaffen" (Bertens \& D'Haen, 1988:9). Hulle vervolg dat die term 'n "interpretatief kader" verskaf waardeur ons in staat gestel word om dinge oor sekere tekste (postmodemistiese tekste) te kan sê, wat andersins nie moontlik sou wees nie. Bertens en D'Haen wil nie hierdie "interpretasieraamwerk" sonder meer as leesstrategie op alle tekste toepas nie. Dit bly 'n leesstrategie wat by uitstek geskik is vir die lees van postmodernistiese tekste. Hierdie beskouing verskil van byvoorbeeld dié van Waugh (in Practising postmodernism/reading modernism, 1992) wat, teen 'n postmodernistiese agtergrond, júis modernistiese tekste lees. Waar Bertens en D'Haen dus die "poststrukturalistiese postmodernisme" as leesstrategie sien, is dit vir Waugh 'n agtergrond waarvan nie ontsnap kan word nie en waarteen enige teks in ons tyd gelees kan word. Kaplan (1996:21) voel ook dat die gebruik van die begrip postmodernisme tot vrugbare debat kan lei en verdedig daarom die gebruik van die term:

In choosing the term [postmodernism - WDB], then, I am not arguing that the 'postmodern' must be recuperated or retained in any ideal sense. As long as the term energetically produces the debates and conversations that accurately signify the material conditions of critical practice, it has use value.

Die reise van Ratkas en Isobelle word ondersoek ten einde te bepaal in welke mate reise in die twee romans (Die ryk van die rawe en Die reise van Isobelle) karakters in staat stel om die meesterverhale wat mense se lewens bepaal, te ondergrawe.

In hierdie artikel wil ek nie 'n pleidooi lewer dat alle reisverhale skielik as postmodernistiese tekste gelees moet word nie. Hierdie is bloot 'n poging om 
reise te bespreek in terme van Lyotard2 (1984) se opvatting van die "postmoderne kondisie". Die ondersoek probeer aandui hoedat alternatiewe punte van waarneming, as gevolg van reise, kan bydra tot die ondergrawing van 'n enkele waarheidsperspektief. Dit is egter nie vanselfsprekend dat 'n reis lei tot alternatiewe waarnemingspunte nie (Die ryk van die rawe) en aan die ander kant bestaan die moontlikheid dat die alternatiewe perspektiewe wel die meesternarratief kan ondergrawe (al kan dit daartoe lei dat 'n alternatiewe narratief weer verhef kan word tot 'n nuwe meesterverhaal) (Die reise van Isobelle).

\section{Die reise van Ratkas en Isobelle}

\subsection{Ratkas Reisiger}

Ratkas Goosen onderneem 'n reis na Europa, aanvanklik vergesel deur sy twee vriende, Jans en JP, maar later op eie houtjie. Wanneer hy aan die einde weer by sy twee vriende uitkom, noem Jans hom "Ratkas Reisiger" (332). Teen hierdie tyd is Ratkas inderdaad 'n gesoute reisiger. Wanneer hy die laaste keer sy rugsak op sy rug swaai, geskied die beweging seepglad, "dit is al geoefen" (334). In Calais sien Ratkas sy eie weerkaatsing in die metaal: "Master of my destiny, dink hy. Net vir vanaand is hy elke reisiger; elke man met die moed om te soek" (292). Ratkas is op soek na 'n "sleutel tot die lewe" wat hom altyd nog ontwyk (15). Sy reis is 'n soektog na 'n ander perspektief op die lewe.

Ratkas dra voortdurend 'n notaboek en pen saam ten einde sy reis te beskryf (13). Telkens wanneer hy in sy dagboek skryf, val dit daarmee saam dat hy sy eie weerkaatsing sien (in die spieël van die vliegtuigtoilet en later in die venster van die moltrein). Hy skryf in die trein: "Wat wil ek hier ervaar? Die geskiedenis, die kultuur, 'n meer globale perspektief - miskien die pubs? Soek ek na 'n deel van myself, uiteindelik?" (22). Terwyl hy skryf, vra Jans: "Dissekteer jy al weer jou siel, hu?" (22). Later lees Jans voor uit Ratkas se dagboek: "Die groot avontuur begin: drie weke van ervaring wat tot dieper insig behoort te lei" (28). Die skrywery wat telkens in ' $n$ voertuig plaasvind en gepaard gaan met 'n selfbeskouing, bevestig die nou verband tussen reis en sy soektog na identiteit. Ratkas se groot vrees is dat alles sinloos is, dat die "reis en al die voorafgaande moeite tot niks behalwe die besef van die sinloosheid daarvan sal lei nie ..." (17). Die kwelvrae waarop Ratkas antwoorde soek tydens hierdie reis, word vir hom

2 Kaplan (1996:17-19) spreek kritiek uit teen die verval van meesterverhale, omdat daar, volgens haar, 'n behoefte is dat meesterverhale moet bly voortbestaan in 'n soort spanning teenoor fragmentering. Sy redeneer dat mense daagliks ly onder meesterverhale van "etniese" opruiming, rassisme, seksisme en ander ongelykhede, en dat een of ander meesterverhaal van sosiale verandering nodig is om hierdie probleme te beveg. 
verwoord deur die "replicant" in die film Blade runner: "Where do I come from? Where am I going? How long have I got?" (17).

\subsection{Isobelle op reis}

Soos die meervoudsvorm in die titel aandui, kom verskeie reise in Die reise van Isobelle (Joubert, Elsa: 1995) ter sprake. Net soos in Die ryk van die rawe word reis ook in hierdie roman geassosieer met 'n soektog, veral 'n soektog na identiteit. Een van die eerste reisigers in dié lywige roman, ds. Josias van Velde, se reis vanaf sy pastorie in Worcester (bewoon deur sy Engelse skoonma en skoonsuster) na die konsentrasiekamp te Springfontein, lei tot ernstige twyfel oor sy eie identiteit:

Die vraag kwel hom: Wat is hy eintlik self? Ingetrou in 'n Engelse familie; sy kinders word half Engels grootgemaak. Sy eie hart verknog aan sy mense. Maar wie is sy mense? Nie sy eie vader en moeder nie, wat ná die oorlog vir eie gewin nog meer verengels het. Wat maak hom dan met hart en siel so deel van die Boerevolk? (58).

Vir die eerste van die drie geslagte vroue wat reise onderneem, Agnes Greylinck, speel die gebrek aan 'n eie identiteit ook 'n belangrike motiverende rol in haar reise. Sy wil ten alle koste deel van 'n familie wees, sodat sy haar eie identiteit kan vind:

'Ek wonder gedurig: Waar kom ek vandaan, wie is ek regtig? Daar by Monumentkoppie het ek gevoel ek is iets. Ek het gevoel ek hoort daar, niemand kan dit van my wegneem nie. Miskien omdat almal ons taal gepraat het. Wie my ouers is het daar nie saak gemaak nie'. Sy begin huil want sy weet sy jok. Die erewagkwessie het haar tog ontstel. Maar sy weet ook nie meer hoe sy voel nie. 'Almal kan terugkyk op iemand of iets, maar ek kan nie. Jy weet nie hoe alleen dit 'n mens laat voel nie' (233).

Agnes onderneem verskeie reise op soek na haar identiteit. Haar eerste lang reis is wanneer sy weggestuur word van haar "vader", Daniël Greylinck. Hierdie reis laat haar met 'n gevoel van ontheemding, sy is 'n identiteitlose weggooikind (waif). Wanneer Agnes uitvind dat sy nie werklik 'n Greylinck is nie, reis sy na die Kaap in 'n poging om haar identiteit te vind. Haar latere reis na die inwyding van die Voortrekkenmonument hou grootliks verband met 'n behoefte aan 'n eie identiteit, om êrens te behoort.

Agnes se soeke na identiteit vuur later haar dogter, Belle, aan om na Kenia te reis. Sy reis enersyds om haar boetie se graf te besoek, maar andersyds ook om haar ma se verlede (en dus haar eie) na te speur. Op ironiese wyse ontneem die reis juis vir Belle van identiteit. Sy kan haarself, na haar ervaring in Kenia, nie meer met haar land assosieer nie. 
Reise word ook ondemeem deur Leonora en die "klein boeties". Leonora besoek Robert waar hy in Nazi-Duitsland studeer. Sy word afgeskrik deur die Nazi's. Hy identifiseer egter ten volle met die Nasionaal-sosialisme en voel dat dit op 'n manier saamgebring moet word na Suid-Afrika.

Leo se reis is nóg na Afrikalande, nóg na Europa. Sy gaan op "reis" na 'n deel van haar land wat deur weinig blankes besoek is. Sy gaan na die townships (na 'n aanvanklike kennisname met 'n deel van haar land se bevolking - waarvan sy nooit bewus was nie - in haar agterplaas) en raak betrokke by die struggle. Sy vind uiteindelik haar identiteit in hierdie deelname.

\section{Reis en die ondergrawing van meesterverhale in die twee romans}

Ratkas se reis is in die eerste plek 'n poging om te vlug van sy verlede. Hy is doelbewus op soek na 'n ander perspektief, 'n ander verwysingsraamwerk. Dit blyk duidelik uit sy teleurstelling aan die einde in die kerk as hy wanhopig uitroep: "Here, tog, 'n mens reis amper tienduisend kilometer om 'n volk te ontmoet met presies dieselfde verwysingsraamwerk waarvan jy wil wegkom" (331)

\subsection{Die reis as ontvlugting}

Ratkas reis om te vlug van sy verlede. Hy lees Edna se grafiese storie (wat op sy lewe gebaseer is) en besef dat die hoofkarakter uiteindelik geen ander keuse het as om aan te hou met reis, met vlug nie: "Where will you go then?" "I will travel," kondig die hoofkarakter dan aan. "I will haunt myself for the rest of my days" (202).

Uit Edna se verhaal blyk dat ' $n$ mens die produk van jou omgewing is. Die hoofkarakter hou aan met groei in die land van die dwerge, net soos wat Ratkas aanhou met lees en studeer en die lewe oordink in 'n omgewing waar dit nie gedoen word nie. Hy bly in "tappet valley" waar hy nie tuis voel nie (135) en Jans noem vir Ratkas selfs " $n$ grease monkey met 'n knack vir trivial pursuit" (135). Die hoofkarakter probeer eers om te vlug uit sy omgewing en later probeer hy wegvlug van sy eie dade (of die moontlikheid van sy dade) (202). Wanneer Ratkas die boekie lees, kom hy "... diep onder die indruk van wie hy is, en hoe graag hy hiervan wil wegkom" (271). Hy is bewus van 'n meesterverhaal wat 'n soort dwang op sy lewe plaas; dat hy die slagoffer van 'n meesterverhaal is. Wanneer hy voel dat hy nie hierby wil of kan inpas nie, voel hy skuldig, soos 'n misdadiger. Die hoofkarakter in die grafiese verhaal se grootste vrees is nie die gepleegde misdryf wat hy probeer ontvlug nie, maar die "onbepaalbare iets" wat hy vermoed hy nog gaan doen (271). Ratkas ontdek homself in Edna se storie (nie in sy eie geskrifte nie). Hy besef dat hy niks met homself te doen wil hê nie en van homself af wil wegvlug. Hy wil ook vlug van God (van wie hy voort- 
durend droom); hy wil vlug van sy eie seksuele probleme en van sy verantwoordelikheidsgevoel teenoor Liesl.

Ratkas probeer om ander perspektiewe te bekom. Hy gesels met Prescott en met Edna in 'n poging om meer te leer; om te soek na die sleutel van die lewe. Hy soek na antwoorde oor God ('n God van wie hy dikwels droom maar wat nie antwoord op sy gebede nie). Prescott voer aan dat die geskiedenis tot stilstand gekom het met 'n middeljarekrisis. Al wat oorgebly het van God, aan die einde van die twintigste eeu, is die "tekens" (relics) van God, soos byvoorbeeld die katedrale (153). Dit is vir die mens nie meer moontlik om iets sinvols te doen nie. Al wat oorbly, is die hersirkulering van afbeeldings - die moontlikheid van 'n oorspronklike lewe bestaan nie meer nie. Hierdie soort gesprek laat vir Ratkas voel asof hy uiteindelik besig is om die "sleutel van die lewe" te ontdek: "Hy is in 'n fassinerende proses betrokke, dié van selfverkenning, dié van uiteindelik grootword" (213).

Ratkas Goosen probeer om sy eie geskiedenis neer te skryf in die notaboeke wat hy oral met hom saamneem. Dit is 'n poging om die meesterverhaal, die verlede waardeur sy lewe gedetermineer word, te beskryf en om alternatiewe te soek. Nadat sy notaboeke gesteel is, ervaar hy 'n gevoel van verligting omdat hy ontslae is van sy geskiedenis. Hy besef dat hy 'n deel van sy lewe daarin opgeteken het, “... wat nou onherroeplik irrelevant geword het en ten beste van nostalgiese waarde kan wees. Dit is goed om afstand te doen: as dit nie so koud was nie, het hy sy klere gelos; as hy nie sou honger word nie, het hy sy geld gelos" (251). Hy breek met sy geskiedenis in 'n "oomblik van waarheid" (264).

Ratkas vertel vir Cathy van sy geskiedenis, van die moeilike omstandighede waarin hy grootgeword het (79). Sy ma het die gesin verlaat toe Ratkas en sy suster nog baie jonk was. Sy pa het begin drink en dikwels gewelddadig opgetree. Ratkas het in hierdie omstandighede 'n baie nou band met sy suster ontwikkel Liesl het in 'n sekere sin 'n moederrol gespeel in sy lewe. Sy het orde gebring in hulle chaotiese omstandighede en hy wil haar nie met seks assosieer nie. Gevolglik is dit vir hom onmoontlik om te kan aanvaar dat sy vriend, Jans, 'n seksuele verhouding met sy suster het en Ratkas ontwikkel 'n weersin in seks. Seks het vir hom 'n bose konnotasie ten spyte van Cathy se vermaning dat seks nie 'n "evil alien affliction" is nie. Ratkas voel ook dat hy 'n verantwoordelikheid teenoor sy suster het. Wanneer hy dus aan die einde hoor dat sy swanger is, voel hy dat hy in sy veranwoordelikheid gefaal het. Hy plaas daarom ook die verantwoordelikheid oor op Jans deur hom te beveel om terug te gaan na Suid-Afrika en die verantwoordelikheid vir Liesl se swangerskap te aanvaar.

Nadat hy en sy twee vriende in London gearriveer het, probeer Ratkas om so vinnig as moontlik van hulle ontslae te raak sodat hy op sy eie kan reis. Hy wil juis alleen wees in die vreemde, waar niemand sy agtergrond ken nie, sodat hy 
homself kan vind. As hy deur ander mense, wat nie van sy verlede bewus is nie, ervaar kan word, kan hy probeer om sy identiteit te bepaal soos wat dit op daardie gegewe moment is. Edna verduidelik aan Ratkas:

... it's not our sins we suffer; it's memory (...) We continually mistake the people we are now for those we were, and so does everybody we know. Only memory links us to past mistakes, and the only way of escaping is by moving among strangers (232).

Die verligting wat Ratkas ervaar met die verlies van sy dagboeke is van korte duur. Black Edna maak daarvan gebruik om 'n grafiese roman te skryf. Hy word dus opnuut met sy eie geskiedenis gekonfronteer wanneer hy hierdie grafiese roman lees. Edna se "comic" is 'n verhaal van "onderliggende wanhoop" (201).

Die woorde wat gebruik word om die hoofkarakter van Edna se verhaal se doen en late te beskryf, het telkens met reis te doen. Dit is duidelik dat die hoofkarakter op "Ratkas Reisiger" gebaseer is: Hy "vlug" om die "groter wêreld te betree" (201), al kan hy nie wegkom van sy jeuginvloede nie. Hy werk as "handelsreisiger" (201) en later as "soldaat wat dros (201); hy "bly egter 'n swerwer" (202). Hy "vlug" weg van die meisie omdat hy 'n gevoel vir haar kry (202). Vroeg in sy lewe sê die seun se pa vir hom: "Who can say which road will take you and where?" (202). In antwoord op die vraag waarheen hy sal gaan na die nag waarin hy 'n meisie verkrag het, antwoord die hoofkarakter: "I will travel (...) I will haunt myself for the rest of my days" (202).

Hierdie hoofkarakter, die misvormde dwerg, is dus gedoem om ewig te reis. Hy het geen ander opsie nie as om 'n swerwer te wees, om voortdurend van plek te verander. Sy reis, sy verplasing na 'n ander omgewing, bring geen verandering in sy perspektief nie. Sy omgewing speel 'n deurslaggewende rol in die bepaling van sy wese. Sy reis is nie 'n reis wat veranderende perspektiewe bring nie. Soos Ratkas, is hy 'n "reisiger na nêrens".

Ook Ratkas is gedoem tot 'n onvermoë om uit sy agtergrond te ontsnap. Ratkas is in opstand teen die geweld in sy verlede. Hy verafsku sy pa se gewelddadige optrede teenoor hom en sy suster en hy wil niks met geweld te doen hê nie (113). Hy toon innige meegevoel met die lyding van ander mense (45). Ten spyte hiervan tree hy gewelddadig op. Hy klap vir Cathy. Hy stamp haar onderstebo by die kaartjiekantoor en voel dan weer jammer en magteloos daaroor. Sy agtergrond bepaal sy wese en hy is sonder beheer daaroor (113). Hy dink daaraan dat dit moeiliker is om van 'n vrou te verskil aangesien jy met 'n man altyd tot geweld kan oorgaan. Dan betig hy homself dadelik (203). Hierdie teenstrydigheid blyk die duidelikste wanneer hy vir Cathy verkrag. Enersyds wil hy dit nie doen nie. Hy is jammer vir haar wanneer hy haar noodkrete hoor, maar hy "wil dit nogtans so hê": ... "En skielik is daar 'n meisie, skielik lê daar 'n meisie op 'n vloer in die 
oopte tussen mense en haar bene is uitmekaar geknak, so wyd uitmekaar geknak, en sy kry seer. My Here, sy kry so seer en dis hy wat dit so wil hê" (260).

Ratkas word deur Edna gemanipuleer om Cathy te verkrag (238). Buite weste gedrink en in die daad ingedwing, besef hy eers die volgende oggend wat gebeur het (250). Dit is vir hom nietemin 'n ervaring wat hom laat voel dat hy nou "'n man" is. Om ' $n$ Man te wees is om te domineer, in beheer te wees, aan die kant van die sterkes te staan. Hy sê vir Edna dat hy dans geniet omdat dit 'n mens laat voel asof jy in beheer is. Hy bewonder byvoorbeeld ook vir Prescott omdat dit lyk asof Prescott sy hele lewe so onder beheer het. Ratkas se reis, sy nuwe ervarings en omgewing help hom nie om 'n ander perspektief op manlikheid te kry nie. Hy bly maar net soos sy eie pa ook was. Hy kan nie die perspektief op manlikheid wat tydens sy jeug in "tappet valley" gevorm is, afskud nie.

Al wat vir Ratkas oorbly, is om te kan "aangaan" (238). Hierdie voortsetting van sy reis is ' $n$ manier om van die verlede te vergeet, dit is 'n volgehoue poging om die meesterverhaal af te skud: "... hierom loop mens so ver as wat jy kan want 'n tree gegee is ' $n$ tree vergete jy kan net aangaaaaaaaaaaaaAAAAAAAN" (238). Om te reis is dus ' $n$ manier om van die verlede en jou eie geskiedenis te probeer ontsnap.

Hy skaf ook maar weer 'n dagboek aan en begin skryf in 'n poging om opnuut te kan begin. Pas na sy terugkeer na London loop hy 'n kerk binne en hoor 'n preek oor Moses in die woestyn. Hy besef dan dat hy nooit daarin sal slaag om van sy verwysingsraamwerk weg te kom nie, dat hy nie uit sy omgewing kan ontsnap nie. Hy kom tot die insig dat geen reis hom sal kan wegneem van wie hy is nie. Sy reis na Europa bring hom bloot tot die besef dat daar niks nuuts is nie, dat dieselfde verwysingsraamwerk ook daar bestaan. Om te reis dien dus geen doel nie. Hy besef dat die reis moet eindig (331). Hy vind dat hy nie werklik 'n skoon blaadjie kan omslaan en sy hele lewe, sy geskiedenis kan herskryf nie. Daarom bly slegs selfmoord vir hom oor. Hy vind geen alternatiewe perspektiewe waardeur die meesterverhaal ondergrawe kan word nie.

Prescott gee uiteindelik ook nie geld aan die bedelaar nie omdat daar geen sin daarin sou wees nie. Die bedelaar sal in elk geval uiteindelik doodgaan: "There seems no point" (340). Hierdie uitsigloosloosheid, die onvermoë om enige alternatiewe perspektiewe vir 'n eksistensialistiese meesterverhaal te bied, lei uiteindelik tot 'n wêreld waarin geen sosiale verandering moontlik is nie Meesterverhale bied gewoonlik beloftes van uiteindelike sosiale verandering. Uit die ryk van die rawe is daar egter geen hoop op sosiale verandering nie. Die dood is die uiteinde van 'n sinlose lewe. Ratkas kan nie, in Spivak se woorde (1990:29), uitvind wat dit is wat weggelaat is uit die meesterverhaal nie. Hy vind nie die beperkings van die meesterverhaal nie 
Teenoor hierdie reis van Ratkas lei die reise in Joubert se roman telkens tot ander perspektiewe; tot die bevraagtekening van die meesterverhaal.

\section{Isobelle se reise}

Die ervarings van Josias van Velde op sy reis as Kaapse leraar na die konsentrasiekamp van vroue uit die noorde het 'n onuitwisbare indruk op hom gemaak: "Nooit weer sal hierdie maande uit sy herinnering gewis word nie" (46). Hy identifiseer met die Afrikanervolk wat deur die Britte onderdruk word. Hy definieer homself teenoor sy ouers wat hulle om sakeredes met die bewindhebbers identifiseer (15). Hy neem standpunt in teen sy skoonfamilie wat met die Britte identifiseer (14). Hy skeur byvoorbeeld die roulappe van die pastorie se deur af wat sy skoonma daar geplaas het na koningin Victoria se dood. Van Velde se reis, wat gelei het tot die waarneming van die enorme lyding van "sy mense", verander sy perspektief op wie "sy mense", wie hyself is (58). Na sy ervaring van lyding, veroorsaak deur die Britte, kan hy nie aanvaar dat sy vrou toegelaat het dat hulle dogter Victoria genoem word nie. Sy identifisering met die Boerevolk word die voorloper vir die nasionalisme wat later 'n eksklusiewe identiteit aanneem in die politieke strewe van sy jonger seuns. Josias van Velde identifiseer egter nie met so 'n eksklusiewe strewe nie en voer aan dat die "passie" nie vir die nasie moet wees nie, maar eerder vir God. Hy sien dat die letsels van die oorlog soveel groter letsels gelaat het as die Groot Griep, ten spyte daarvan dat meer mense tydens die Griep gesterf het. Hy besef dus dat dit gaan om die máák van 'n geskiedenis - die oorlog het 'n groter blywende effek vir die geskiedskrywers as wat natuurlike dood deur siekte het (107). Hy noem die manier waarop die verlede, die oorlog beskryf word, "selfregverdigende emosie" (107). Op hierdie manier word te werk gegaan om 'n narratief van nasionalisme te vestig.

Die jong Valeria Agnes Greylinck se reis saam met Daniël na Kenia (Brits-OosAfrika), en haar verblyf daar saam met hom beïnvloed haar hele lewe (59). Haar kortstondige verhouding met die nuiter tydens die 1938-Ossewatrek is 'n poging om weer iets van Daniël en haar jeug in Kenia terug te vind. Vir Agnes ruik die deelnemers aan die 1938-Ossewatrek na "man en na perd en na sweet", soos wat Daniël geruik het (201).

Agnes se reis van drie maande saam met die Portugese handelaars, gedra in 'n masjila (61) het by haar 'n perspektief van verwerping gelaat - die perspektief van 'n waif wees, wat sy nooit werklik afgeskud kry nie. Die brief van Irma Greylinck waarin verduidelik word dat Agnes nie regtig Irma of Daniël se kind is nie (113), lui Agnes se soektog na identiteit in: "Niemand, dink sy, kan ek tog nie wees nie" (115). Sy onderneem 'n reis na Kaapstad op soek na haar herkoms (126). Sy sê vir die bestuurder van die losieshuis: "Mens wil tog weet waar jy 
vandaan kom, wie jy is" (129). Agnes probeer om die onsekerheid oor haar herkoms te ignoreer: "Ek gaan in hierdie nuwe wêreld 'n nuwe lewe binne" (129). Dit is egter nie vir haar moontlik om haar onseker herkoms af te skud nie. Sy weet nie wat om vir Stuart se familie te sê oor haar herkoms en familie nie (135) en vrees verwerping. Vir jare onhou sy steeds haar pa (op sensuele wyse) en vrees altyd dat sy "uitgevang" sal word dat sy 'n weggooikind is (129). Dit is tydens haar reis na die Voortrekkermonument en die herontmoeting met die ruiter, dat Agnes se perspektief op haarself as weggooikind kortstondig verander. Haar seksuele verkeer met die ruiter is 'n lang reis. Wanneer die ruiter haar liggaam begin verken "is die reis nog ver, nog ver" (227). Dit is 'n reis waartydens die grond en doringbome en alles van die sensuele wat sy van haar vader onthou, een word en sy vir die eerste keer voel dat sy nie verwerp is nie: "So is dit reg, hier voel sy tuis" (227). Dit is egter van korte duur. Na afloop van hulle intieme verkeer fluister sy: "Maar jy het my weggestuur" (227). Die reis se veranderde perspektief is dus van korte duur. Die groen rok wat tydens die hartstogtelike oomblikke geskeur word, bewaar sy tot aan die einde van haar lewe as herinnering aan daardie dag.

Die 1938-Ossewatrek is 'n reis uit al die uithoeke van die land, wat daarin slaag om 'n nuwe meesterverhaal te vestig. Die ou tante spel die effek van die simboliese reis uit: "Hulle het my daar op die show-grounds na iets laat voel (...) Iets wat ek nie geweet het ek is nie" (203). 'n Nuwe identiteit word tydens die ossewaens en deelnemers se reis na die Voortrekkermonument geskep deur die identifisering met (werklike of gewaande) helde ${ }^{3}$ en heldedade uit die verlede. Dit is 'n heldeverering wat ook met die religieuse verbind word. Vir Belle is die Trek 'n godsdienstige gebeurtenis want die "mense sing amper net psalms en gesange" (203). Deur die nasionalistiese met die godsdiens te verbind, word religieuse sanksionering daaraan verleen. Belle is so aangedaan oor haar deelname aan die fakkelloop dat sy sê: "ek was nie meer ek nie, maar iets anders" (209). Agnes se voorkoms verander ook met die aantrek van die rok vir die kooruitvoering by die Voortrekkermonument. Die identifisering met die groep, tydens hierdie reis na Pretoria, hef haar uit haar vaal voorkoms en saai, identiteitlose bestaan. Sy is wel 'n weeskind maar voel dat sy 'n tuiste vind in hierdie groep (211).

Oor Leonora se reise na London is nie veel bekend nie (165). Tydens haar tweede reis in 1939 besoek sy haar jongste boetie, Robert, in Duitsland. Hy verduidelik dat hy die Afrikanervolk 'n opbloei van selftrots gun, net soos hy dit vir die Duitsers gun (222). Sy kan nie met hierdie hartstog vir die volk, hierdie opbloeiende nasionalisme saamstem nie. Sy skryf ook jare later aan Frikkie oor

3 Dit is byvoorbeeld vir die latere geslagte ondenkbaar om Braampie, die volksheld, te verdink van 'n buite-egtelike verhouding. 
hulle jonger broers se passie vir die volk, dat "hartstog vir 'n saak" hulle "verwring" het (492). Van Velde het hulle geleer dat hartstog nie vir 'n saak moet wees nie maar vir God.

Leonora reis saam met vriende na die Karoo vir 'n naweek. Hier dink sy aan Jesus wat ook in die woestyn ingegaan het. Sy is egter bang vir dit wat sy "in die onmeetlike nag in die woestyn sal vind" (261). Sy is nie bereid om die eensaamheid van die woestyn in te gaan nie en is nog nie gereed vir die verandering van perspektief wat so 'n "reis" sou bring nie. Sy onderneem hierdie reis, stel haarself uiteindelik oop vir die verandering, eers wanneer sy baie oud is. Saam met die twee bergies op die stoep, "reis" sy uiteindelik die nag in, dié reis waarvoor sy vroeër teruggedeins het. Sy kom tot die insig dat die aandster die môrester word: "Die vernuwing wat uit die self kom. Die hergeboorte. Die herrysenis" (597). Haar lewe, as lang reis, bring haar uiteindelik by die perspektief wat haar vader aan die begin vir haar wou gee. Sy perspektief dat slegs op die genade aanspraak gemaak kan word, dat mens moet skep (597), word eers aan die einde van haar lewe vir haar duidelik. Wanneer Leo en Fred vir Leonora gaan aflaai by die ouetehuis, besef hulle dat " $n$ hele era aan die verbygaan is" (600). Hoewel dit vir haar nie maklik is nie, verwelkom Leo die verbygaan van die era. Dit is die einde van 'n sekere meesterverhaal. Enkele mense klem nog daaraan vas Robert vanweë sy ideologiese oortuiging, Hendrik vir die finansiële voordeel wat dit bied. (Die noue band tussen die nasionalisme en die kapitalisme in hierdie meesterverhaal word hierdeur bevestig.) Barry verlaat die land omdat hy nie van perspektief kan verander nie. Dit is slegs Leo (en haar naamgenoot, Leonora) wat kan soek na die "moontlike anderkant die onmoontlike", wat kan "skep van die water".

Wanneer Belle na Kenia reis, voel sy dat haar ma se angs, haar onsekerheid oor haar identiteit, "in haar gevaar het" (306). Nadat Hussein voor haar (en as gevolg van haar) doodgeskiet word, verloor haar reis ook sin. Sy besef die onhoudbaarheid van die apartheidsisteem en wil nie meer met die land geassosieer word nie (359). Sy voel totaal ontheem. Die vrou in Geneve vertel haar dat hulle probeer om "n eienheid" aan die lewens van die mense in vlugtelingkampe te gee. Belle soek na haar "eienheid" maar weet nie wie sy is nie (365). Sy wil afgesny van haar land se mense lewe. As sy dit nie doen nie, is dit verraad teenoor Hussein en teenoor haarself want sy het haar eienheid slegs in sy liefde gevind (365). Belle kan nie meer lief wees vir haar land nie. Sy kyk na die foto's en briewe van die Kaapse rebel, Braampie, en sê vir oom Frikkie:

Dis hoe hulle ons emosies verfoes het. Hulle maak jou kleintyd met so 'n sterk lym vas dat as mens jou wil wegskeur, jy nie maklik van die wond herstel nie. As mens enigiets wil doen omdat dit vir jou persoonlik reg is, dan word jy skoon skisofrenies. (...) Hierdie vaderland wat iets reins, iets moois, iets edels moet wees, is slegs ' $n$ mite, ' $n$ chimera, 'n opgeefsel. Iets 
soos (...) 31 Februarie ... 'n onmoontlikheid, onbereikbaar, waarin jy tevergeefs moet glo (389).

Belle se reis deur Afrika en die liefdesverhouding met Hussein in Kenia laat haar perspektief verander. Sy sien die meesterverhaal van Afrikaner-nasionalisme vanuit ' $n$ ander perspektief (uit die buiteland). Die meesterverhaal van Afrikanernasionalisme is iets waaraan sy nooit weer kan glo nie. Sy kan nie met die "skisofrenie" saamleef nie. Sy probeer om daarteen te rebelleer deur betrokke te raak by die hofsake, die worsteling saam met die vroue teen apartheid, maar word uiteindelik tot 'n willose oorgawe gedwing in die kliniek (deur haar ooms). Die ooms se vrese is dat hulle, as gevolg van haar optrede, as "andersdenkend" verklaar kan word en dat dit hulle loopbane kan ruïneer (283). Hulle doen dus alles in hulle vermoë om die meesterverhaal in stand te hou.

Aanvanklik is Leo onkundig oor die nasionalistiese (en kapitalistiese) narratief. Die koshuismeisies se gesprekke om die koffiekan maak haar effens bewus van moontlike ander perspektiewe (476-477). Dit is egter eers wanneer sy "reis" na die "onbekende dele van haar land", soos na haar agterplaas waar sy die straatkinders ontdek en na die township waar sy skoolhou, dat haar perspektief sodanig verander dat sy aktief meewerk om die meesterverhaal te ondergrawe. Sy wil nie deur haar saamwerk in die struggle en die trots om as "comrade" aangespreek te word, losgemaak word van haar Afrikanerskap nie. Sy sê vir Barry: "Ek het ook 'n gevoel vir die volk en vaderland, oom - hoe benouend dit ook al was. En dis bitter swaar om te moet vra: Was volk en vaderland net 'n opgeefsel? lets wat ons ons wysgemaak het? Oom, my enigste manier om dit te verwerk, is om te probeer help dat die onreg wat hulle aan ander mense doen, end kry" (554). Leo is in verset teen die meesterverhaal omdat die strukture daarvan menslike lyding veroorsaak.

\section{Die sukses van die reis}

Ten spyte van haar aktiewe deelname aan die struggle word Leo tog soms beskou as 'n "bleeding heart white liberal" (573). Sy weier om soos Barry die land te verlaat om weg te kom van die geweld, of om soos Fred uit die land te gaan op soek na ander uitdagings. Sy wil in Suid-Afrika bly en aanhou glo in die "moontlike verby die onmoontlike" (616). Dit wat haar ma nie kon regkry nie, daarvoor is sy sterk genoeg. En sy sien daarna uit om haar kind daarvoor groot te maak. Sy vind 'n manier om die meesterverhaal te ondergrawe en sien daarom kans om nuwe lewe die wêreld in te bring, in teenstelling met Ratkas wat verkies om 'n einde aan sy lewe te maak.

In Die reise van Isobelle word die meesterverhaal van Afrikaner-nasionalisme ondergrawe deur die hele geskiedenis te herskryf sodat die aanbreek van die postapartheid Suid-Afrika as die logiese uiteinde van die verhaal voorkom. Hierdie 
slot staan in kontras teenoor die meeste geskiedenisboeke wat republiekwording as teleologiese eindpunt neem. Die narratiewe waarin die suksesvolle slot die uitloop op 'n onafhanklike republiek vir die Afrikaner is, word ondermyn. Die "reise van Isobelle", van die titel, is in der waarheid slegs 'n enkele reis - 'n reis waarin een perspektief plek maak vir 'n ander. Die beperkings van die een narratief word blootgelê, sonder om twyfel in die nuwe narratief te hê. Die ongebore Isobelle sal dus weer op reis moet gaan ten einde die beperkings van hierdie narratief bloot te lê.

Leo aanvaar dat daar 'n versoening is tussen haar identiteit as Afrikaner en die Suid-Afrikaanse realiteit. Vir Ratkas is dit nie moontlik om so 'n perspektief te bekom nie. Hy reis na Europa op soek na 'n geestelike tuiste, 'n eie identiteit. Edna sê uiteindelik vir hom dat dit nie moontlik is om 'n tuiste, 'n eie identiteit te vind nie:

You and me, we're unfortunate in that respect, South African. We have actually intruded upon another's history, another's spiritual frame of reference, which we can investigate but never adopt. I pity you. You live in Africa but you will never be of it. And you can find that you can visit Europe but that you've left your home - you're like a child returning for Christmas (206).

Ratkas se identiteit word bepaal deur 'n spesifieke perspektief. Sy perspektief is bepaal deur sy omgewing. Al die kennis wat hy opdoen deur die lees van boeke help hom niks, gee hom bloot 'n "knack vir trivial pursuit". Hy probeer sy perspektief verander deur uit die omgewing pad te gee, maar kry dit nie reg nie. Hy kan nie van die verwysingsraamwerk wat vir hom oral dieselfde bly, ontsnap nie. Ten spyte van sy reis en die verandering van perspektief wat dit veronderstel is om teweeg te bring, bly Ratkas in dieselfde (eksistensialistiese) verwysingsraamwerk. Ratkas se onvermoë om die meesterverhaal te ondergrawe, lei tot sy dood. Hy bly 'n slagoffer van die meesterverhaal. Sy nuut verworwe "insigte" bring hom bloot dieper onder die indruk van die meesterverhaal. Die onvermoë om 'n meesterverhaal te bevraagteken kan dus tot dood lei. Ratkas se enkele waarheid word so oorheersend dat hy geen uitweg kan sien nie. Leo daarenteen, vind 'n alternatiewe narratief. Gevolglik eindig die roman nie met die dood nie maar met die belofte van 'n nuwe lewe.

Die wins van reis lê daarin dat die reisiger se perspektiewe verander. Die reisiger word bewus daarvan dat sy/haar eie perspektief op die wêreld nie die enigste geldige perspektief is nie. Uit hierdie bespreking blyk dat reis nie noodwendig lei tot die proliferering van 'n verskeidenheid perspektiewe, wat verbind kan word aan 'n postmodernistiese twyfel in alle meesterverhale nie. In Die ryk van die rawe slaag die reisiger nie daarin om die meesterverhaal te ontkom nie, terwyl reise in Joubert se roman wel lei tot die ondergrawing van 'n meesterverhaal, 
maar die meesterverhaal word vervang deur ' $n$ ander (wat aansluit by die idee van Caren Kaplan dat meesterverhale nodig is ten einde sosiale verandering aan te bring).

\section{Bibliografie}

Bertens, H. \& D'Haen, T. 1988. Het postmodernisme in de literatuur. Amsterdam : Uitgeverij De Arbeiderspers.

Fouché, Jaco. 1996. Die ryk van die rawe. Kaapstad : Queillerie.

Joubert, Elsa 1995. Die reise van Isobelle. Kaapstad : Tafelberg.

Kaplan, Caren. 1996. Questions of travel: Postmodern discourses of displacement. Durham Duke University Press.

Lyotard, J-F. 1984. The postmodern condition. Manchester : Manchester University Press.

Spivak, G.C. 1990. The post-modern condition: The end of politics? In: Harasym, S. (ed.) The post-colonial critic. Interviews, strategies and dialogues. New York : Routledge. p.1734.

Waugh, P. 1992. Practising postmodernism/reading modernism. London : Arnold. 
